\title{
Segmentation Strategies of Mpu Tantular Museum
}

\author{
Alshaf Pebrianggara \\ Magister Manajemen \\ Universitas Muhammadiyah Sidoarjo \\ Sidoarjo, Indonesia \\ alshafpebrianggara@gmail.com
}

\author{
Putri Sania Riska \\ Magister Manajemen \\ Universitas Muhammadiyah Sidoarjo \\ Sidoarjo, Indonesia
}

\author{
As'at Rizal \\ Magister Manajemen \\ Universitas Muhammadiyah Sidoarjo \\ Sidoarjo, Indonesia
}

\begin{abstract}
Tourism is one of the biggest aspects can be overviewed through economic and socio-cultural point of view. Therefore, the tourism industry encourages the creation of employment and income improvement for the society. sThis research uses a descriptive method approach. Data collection technique uses observation and documentation. Analysis technique uses SWOT analysis and Research object in Mpu Tantular Museum. Primary data sources taken from interviews and observation. Secondary data sources are based on literature and documentation. The results are based on SWOT analysis of internal and external factors based on the influence of each factor obtain from IFAS matrix and EFAS matrix. The result of marketing strategy position of MpuTantular Museum on aggressive strategy, demographic segmentation of the market that must be done is to cooperate with educational institutions, and by conducting MpuTantular Festival, exhibition of museum collections, demonstration of museum collections, educational contest. With the aggressive strategy is expected MpuTantular museum can increase tourist visits.
\end{abstract}

Keywords—SWOT; Mpu Tantular; tourist

\section{INTRODUCTION}

Tourism is one of the biggest aspects can be overviewed through economic and socio-cultural point of view. Therefore, the tourism industry encourages the creation of employment and income improvement for the society. Since many tourism objects are supported to be made as tourist attractions, the development of tourism are also increasing rapidly. Tourism can be the potential economic income for either government or the society because it is able to attract domestic and foreign tourists, if they are managed well and maximally. The fact shows that there are more tourism sectors that currently attract more and more society. Museum is a formal body that has duties and activities to exhibit and publish the results of research and knowledge about the objects that are important for cultural and scientific knowledge.

Objects that have historic objects kept within the museum now seemingly more neglected by most people, so the manager of the museum must work hard to compete in attracting the public to visit the museum as a means of education or just a recreation by doing some marketing strategies. Aristitoteles stated that history is a system that examines one event from the beginning and is arranged in chronological form. At the same era, he also said that history are past events that have records, records, or concrete evidence.

Marketing strategy is a statement about how a brand or product line reaches its goal. A marketing strategy can be defined as a marketing mindset that will be used to achieve marketing goals [1]. Segments of some researchers from descriptive characteristics of geographic,demographic, and psychographic[6]. Mpu Tantular Museum of East Java Province is located on Jl. Raya BuduranSidoarjo which was inaugurated on May 14, 2004. It was inaugurated firstly on June 25, 1937. The primary visitors of the museum MpuTantular are of primary school, junior high school and senior high school students. The museum itself serves as a channel capable of expressing a history. Mpu Tantular Museum needs to hold a re-interpretation of the importance of increasing tourist interest for tourists to function museum as a medium of delivery of messages of history and culture can go well.

\section{RESEARCH METHOD}

The type of research is descriptive qualitative where a research method that explains or explain a state or phenomenon what happens in accordance with actual events on the object of research and obtained data descriptive that is in the form of oral or written data in the form of reports related to research to be drawn a conclusion. The research used purposive sampling technique with sampling of data source with certain consideration which is considered to be most understood, so it will make it easier for researchers to explore the object or social situation under study.Data collection is done by direct observation method. This method requires the researchers to come and observe objects closely to find out the activities undertaken through interviews with leaders and employees. The information needs of the research includes a number of questions about management and marketing strategies. Documentation is also done to obtain data related to 
research in the form of documents, tourist visits, as well as facilities and infrastructure that has supported the museum management and marketing. The technique of analysis of research using SWOT, where to analyze the situations and conditions that are descriptive, to identify internal and external factors.

SWOT analysis is used to identify internal factors including strength (Strength), weakness (Weaknesses) and external factors include opportunities (Opportunities), threats (Threats) [3]. So, from the SWOT analysis, policy strategy can be formulated. This analysis can maximize the strengths and opportunities and simultaneously can maximize weaknesses and threats that can be based on logic[4]. Stages of analysis in the SWOT is utilizing the overall data and information in the model of quantitative model of strategy formulation[2]. Processing of several strategic factors in the internal and external environment in each tourism object by giving a weight and rating on each strategic factor. It possesses an understanding of internal and external strategy factor analysis. Consistent factors of strength, weakness, opportunities and threats that dominate the effect on the situation conditions that exist and will provide great benefits on the attraction when done with appropriate positive action[5].

\section{RESEARCH RESULT}

SWOT analysis method is used to identify internal and external factors, weaknesses, strengths and opportunities, and threats. The internal strength factor of this museum is that it has a very affordable tariff for students and society. Activities that attract tourists include exhibitions, Tantular Festival in various forms of activities including thematic exhibitions, museum collection surgeries, museum collection displays, and cultural educational contests, which have been conducted annually with different activities. Facilities are very supportive, which includes a permanent exhibition building that showcases the collection comes from prehistoric, classical (Hindu-Budhist), Islamic, colonial and modern times, including the collection of science and technology. The Von Faber building is used for seminars, performances and temporary exhibitions. The blind exhibition building for visitors with special needs using braille letters to describe it so that visitors know the existing collection and exhibition building of science and technology for modern technology and science and technology display that can be used for media practice for tourists. The library is equipped with a wide variety of general science books. Pendopo for visitor activities drawing, coloring, dancing, theater, making batik, and singing "macapat". The parking area is quite extensive for tourists to use. Activity budgets are always available because the funds provided by the provincial government are sufficient.

The aspect of weakness includes a less strategic place. This refers to a museum route that is not a main road for road users so this mueum is not visible to potential travelers. Directions are also few in number, so visitors will find it difficult to find a place or building to be searched. The exhibition space is also limited so that all museum collections more than 15,000 pieces can only be exhibited a small portion.
External factors, namely opportunity, exist in the growth of primary, middle, and upper level schools. Government policy No. 19 of 2005 article 19 states that the learning process is held interactively, inspiration, fun, challenging, motivate learners to participate actively and provide enough space for initiative, creativity, and independence according to talents, interests and developments. Cooperation networks are needed to increase traffic, especially with people outside East Java.

The element of threat shows the fact that public is less interested in museum tourism because there is still selfgenerated perception about the museum. The number of tourist attractions to be a tourist choice, so that the museum is only an alternative choice for tourists.

Determination of internal and external weight and rating factors based on the influence of the size of each factor on the marketing strategy. The results obtained from the IFAS matrix $1.79-1.45=0.34$ and obtained from the EFAS matrix are 1.45$1.21=0.24$, where the result of the SI diagram shows a very favorable situation for the museum, where there is still opportunity and strengths so that it can take advantage of existing opportunities by directing all the internal potential. The strategy adopted under these conditions is to support an aggressive growth policy to continue to grow. S II shows the existence of various threats, but the museum still has internal strength. Therefore, the strategy to be implemented is to use the strengths to take advantage of long-term opportunities with a diversified strategy or innovate by harnessing the strengths to enable the creation of opportunities in the future. S III shows the museum faces a huge market opportunity, but also faces some internal weaknesses. In this case, the strategy is focused on minimizing internal problems so as to seize market opportunities well. S IV shows a very unfavorable situation, with a variety of internal threats and weaknesses. This strategy is focused on taking rescue action to be free from greater losses by defending itself to build internal strengths and minimize weaknesses.

\section{DISCUSSION}

Based on the SWOT analysis diagram, the museumseems to be in the position of aggressive strategy whereas in SWOT matrix, the most dominant strategy is SO strategy (Strenght and Opportunity), the policy must be done with market segmentation strategy based on demographic segmentation which is the group of early age children up to university. The need for cooperation and visits of the museum management to schools is compulsory to build cooperation in order to attract tourist visits. With the government policy on the curriculum that is in particular study tour, the level of learning method for the group of students must be made in a lighter content, easier to understand, fun and interesting and cause motivation so that tourists will feel more interested in choosing a place of tourism that can be as a place of recreation as well as a place of study. This will be something that can increase tourist visits for the future. The otherimportant matter in increasing tourist visit is by maximizing infrasturcture and support so that visitors can be more comfortable when visiting museum. This 
can be done by providing canteens complete with food and beverages, playgrounds are maintained with attractive displays, and also providing a typical souvenir center for tourists.

The analysis result obtained a problem solving that the management needs to use aggressive strategies based on demographic market segmentation. It is because it has had the opportunity and internal strength so that the utilization of opportunity by directing all potency to keep growing and reaching profit in the future in progress and development museum, is needed. Aggressive strategy can be implemented in market segmentation strategy which is done and developed in more variant such as maximizing Tantular Festival which is held every October exhibition of museum collections, demonstration of museum collections and cultural educational contest, cultural savvy contest, coloring contest of museum and traditional game competition, and also national exhibition of traditional musical instruments.

Visitor services include brief briefings on museum information, film screenings of historic relics, view of exhibition space and traditional games to the level of education. Implementation of appropriate strategies is expected to increase the level of tourist visits.

\section{CONCLUSION}

Based on SWOT analysis results, it can be obtained that an aggressive strategy is needed by using the strengths to exploit the opportunity of magnitude to increase tourist visits by doing market segmentation strategy based on demographic segmentation, i.e (1) doing re-visits to some reputable schools in certain areas that have strategic position by cooperating with several nearby schools. Making nearby schools to attend is the right way to gain great opportunities to increase tourist visits. Strengthening cooperation with certain large educational institutions with the aim that more tourists who visit is also important. (2) The learning method needs to be designed in a lighter content and need to be easier to understand, fun, interesting, and cause motivation so that tourists will feel more interested in choosing a place of tourism in it as a place of recreation as well as a place to learn. This will be something that can increase tourist visits. (3) Improvement of tourism support facilities to be better and fun for visitors by age groups. Improved facilities are also needed, including canteens, playgrounds, and souvenir shops typical for tourists.

\section{ACKNOWLEDGEMENT}

Special thanks to my lecture Dr. As'at Rizal, MM and my partner Putri Sania Riska for all their efforts to help make this research. And many people in Universitas Muhammadiyah Sidoarjo provided immeasurable assistance to make this research finish.

\section{REFERENCES}

[1] T. Fandy. 2015. Strategi Pemasaran. Penerbit Andi, Edisi 4, Yogyakarta.

[2] Sugiyono. 2013. Metode Penelitian Kuantatif Kualitatif. Cetakan Ke-19, Alfabeta, Bandung.

[3] R. Freddy. 2001. Analisis SWOT : Teknik Membedah Kasus Bisnis. Jakarta: PT.Gramedia Pustaka Utama, Jakarta.

[4] R. Freddy. 2006. AnalisisSWOT : Teknik Membedah Kasus Bisnis. Jakarta :PT.Gramedia Pustaka Utama, Jakarta.

[5] R.G. Dyson. 1990. Strategic Planning : Models and Analitycal Technique. England : John Wiley \& Sons Ltd.

[6] P. Kotler \& K.L. Keller. 2009. Manajemen Pemasaran, Jilid 1, Edisi 13, Erlangga, Jakarta.K. Elissa, "Title of paper if known," unpublished.

[7] R. Nicole, "Title of paper with only first word capitalized," J. Name Stand. Abbrev., in press.

[8] Y. Yorozu, M. Hirano, K. Oka, and Y. Tagawa, "Electron spectroscopy studies on magneto-optical media and plastic substrate interface," IEEE Transl. J. Magn. Japan, vol. 2, pp. 740-741, August 1987 [Digests 9th Annual Conf. Magnetics Japan, p. 301, 1982]

[9] M. Young, The Technical Writer's Handbook. Mill Valley, CA: University Science, 1989. 